KEYWORDS

Interest rates

Bank loans

Commercial banks

Economic analysis

Monetary policy

Central banks

Bahamas

Barbados

Daniel O. Boamah

Deputy Governor,

Central Bank of Barbados

•doboamah@centralbank.org.bb

Mahalia N. Jackman

Economist, Research Department,

Central Bank of Barbados

œmnjackman@centralbank.org.bb

Nlandu Mamingi

Professor of Economics,

Department of Economics,

University of the West Indies,

Bridgetown, Barbados

œnlandu.mamingi@cavehill.uwi.edu
CEPAL REVIEW 103 A PRIL 2011

\section{Bahamas and Barbados: empirical evidence of interest rate pass-through}

\author{
Daniel O. Boamah, Mahalia N. Jackman and Nlandu Mamingi
}

$\mathrm{T}$

his paper uses an error correction model to investigate empirically the effectiveness of central bank interest rate policy in influencing commercial banks' lending rate behaviour in Barbados and the Bahamas using quarterly data for the period January 1995-April 2007. For Barbados, the study finds that the reaction of commercial bank lending rates to changes in the central bank's policy rate is sticky in the short run, but fully complete in the long run. On average, it takes about four to six quarters for the full effect of changes in the central bank policy rate to be transmitted to the economy via adjustments. For the Bahamas, the reaction of commercial bank lending rates to changes in the central bank policy rate is fully complete in the short run and the long run, owing to a low adjustment cost coupled with the use of moral suasion. 


\section{I}

\section{Introduction}

Any government can use at the very least fiscal policy or monetary policy, or both, to impact the country's macroeconomic aggregates such as the inflation rate, unemployment and economic growth. While government taxes and government expenditures are the main tools of fiscal policy, interest rates and the money supply are the key instruments of monetary policy. The choice of one policy over another or the policy mix depends on the characteristics of the country under consideration, i.e. its exchange rate regime, level of development and size of its economy.

This paper addresses the issue of interest rate passthrough in the context of two small open economies with fixed exchange rate regimes, Barbados and the Bahamas. Specifically, it analyses the dynamics of commercial banks' lending rate reactions to changes in the central bank policy rates of those two countries in the period 1995-2007 with quarterly frequency; hence, it deals with the effectiveness of interest rates in influencing the Barbadian and Bahamian economies. In particular, it focuses on the following questions. First, does the central bank policy rate affect the commercial bank lending rate? Second, if so, how large is the short-term and long-term interest rate pass-through in each country? Third, what is the minimum response time for the central bank's actions to impact on commercial banks' average lending rate? Fourth, how do the two countries compare in terms of monetary policy?

As is well documented, central banks' vital influence on money market conditions, and particularly on money market interest rates, places them at the heart of monetary policy. Changes in money market interest rates affect market interest rates with longer maturities and retail bank interest rates, albeit to varying degrees. Bank decisions regarding the yields paid on their assets and liabilities have an impact on the expenditure and investment behavior of holders and thus real economic activity. In other words, a quicker and fuller pass-through of official and market interest rates to retail bank interest rates strengthens monetary policy transmission and thus may affect price stability. Furthermore, prices set by banks influence their margins and therefore bank profitability and consequently the soundness of the banking system and thus financial stability (De Bondt, 2005, pp. 37-38).
This study focuses on the lending rate mainly because, among the myriad commercial bank interest rates, it is the main channel through which monetary policy action is transmitted to the real economy, since it serves as an important guide to investment decisions. ${ }^{1}$ This view is supported by the work of Borio and Fritz (1995, p. 3) and Oliner and Rudebusch (1995, p. 3). For instance, the latter study points out that the lending rate channel operates when central bank actions affect the supply of loans from depository institutions ("banks") and, in turn, the real spending of bank borrowers.

Quite a number of papers have documented various degrees of lending rate stickiness (Moazzami, 1999; Cottarelli and Kourelis, 1994; De Bondt, 2005; Kwapil and Scharler, 2006). The reasons for interest rate passthrough variations may be found, among other things, in different adjustment costs, the demand elasticity of loans, implicit contracts between banks and their customers, switching costs and asymmetric information costs (see, among others, De Bondt, 2005; Kwapil and Scharler, 2006). Put rather differently, the degree of lending rate stickiness depends on the extent to which (i) commercial banks are able to fully insulate their supply of loans in response to changes in reserves; and (ii) borrowers are able to insulate their spending from alterations in the accessibility of bank loans (Oliner and Rudebusch, 1995, p. 3).

At least three considerations justify the present study. First, the concern expressed by the Governor of the Central Bank of Barbados at the apparent slow response of commercial banks' lending rates to recent reductions in the minimum deposit rate (Barbados Business Authority, 2008, p. 1) suggests a need for a quantitative investigation to shed some light on the problem. Second, an understanding of interest rate passthrough provides useful insight into the transmission mechanism of monetary policy, and should provide policymakers with a general idea as to when a particular policy action can be expected to have an impact on the real economy. Third, a comparative study of countries

\footnotetext{
1 The lending rate is one of the determinants of foreign direct investment in Barbados, as tested by an error correction model which indicates that the weighted average rate on total loans Granger-causes foreign direct investment in the period 1995-2005. The relationship between the two variables is significant (results are available upon request).
} 
such as Barbados and the Bahamas is more than relevant as it may help reveal the effective role of monetary policy in similar economies.

To answer the different questions of the paper, use is made of an error correction model derived from a partial adjustment model. This popular model is chosen purely and simply to see how effective it is in capturing the pass-through phenomenon in Barbados. The paper makes two contributions to the literature. First, given that most studies focus on developed countries, this paper, by concentrating on small Caribbean economies,

\section{II}

\section{Stylized facts}

The Bahamas and Barbados are islands that share similar economic characteristics. Specifically, they are both small open economies whose currencies have been pegged to the United States dollar at parities of BDS\$ 2 to US\$ 1 (for Barbados) and B\$ 1 to US\$ 1 (for the Bahamas). In addition, economic growth in both countries is strongly supported by a vibrant tourism sector, accounting for about $60 \%$ of gross domestic product (GDP) in the Bahamas and 15\% in Barbados, and impressive financial services.

Commercial banks hold a dominant position in both countries' financial systems. Since they are the main source of finance in the economy, the interest rates set by these banks strongly impact the investment and consumption decisions of individuals and firms and, by extension, economic development in these countries. Hence, the monetary policy of the central banks of the Bahamas and Barbados has, to a large extent, been geared towards influencing interest rate developments in the commercial banking sector. The following subsections discuss the data trends for selected interest rates in both Barbados and the Bahamas over the sample period 1995-2007.

\section{Barbados}

The Central Bank of Barbados currently uses a combination of direct and indirect instruments to influence interest rates. These include a saving rate floor, a discount rate and reserve requirements. The minimum deposit rate has served as the main monetary policy tool since the 1990s, with changes in the discount rate and reserve requirements playing a secondary role. Prior to 1991 , the banking sector was subject to a number of other adds to the rather sparse body of knowledge on banking sector behaviour in developing countries. Second, this study is among the very few to compare two small open economies with fixed exchange-rate regimes.

The paper is organized as follows. Section II briefly introduces the Barbadian and Bahamian economies, with emphasis on central bank and commercial bank interest rate paths. Section III reviews the literature. Section IV focuses on modelling. Section $\mathrm{V}$ gives the results and interpretations of the exercise, and section VI contains concluding remarks. restrictions and regulations, including programmes geared towards channelling funds to priority sectors of the economy, with stipulations on saving rate floors as well as ceilings on weighted average lending rates imposed by the Central Bank of Barbados. Accordingly, movements in commercial bank interest rates were generally governed by the central bank.

In the early 1990s, macroeconomic developments in Barbados were characterized by the turmoil in the global economy as a result of the Gulf war and by recessions in Barbados' main tourism source markets, i.e. North America and the United Kingdom. The Barbados economy experienced a significant fall in real economic activity and persistently high current account deficits resulting in significant losses in foreign exchange reserves. To combat the foreign exchange shortfall, in May 1991 the government entered an 18-month stabilization programme with the International Monetary Fund, prompting financial sector reform. Of particular note, the ceiling on average lending rates was removed.

The financial sector continued to undergo reform throughout the 1990s. The Rate of Interest Order was revoked in June 1992, the residential mortgage rate had been deregulated by September that year and all credit caps and controls had been discontinued by May 1993. Throughout the remainder of the 1990s, there were moderate fluctuations in minimum deposit rates as monetary policy was geared towards managing the level of liquidity in the financial system. Lending rates were fairly stable, however (fluctuating around 11\%), suggesting a rather low pass-through of changes in monetary policy to lending rates following liberalization of the latter. 
From 2000 to 2004, the banking sector was characterized by high levels of liquidity, a consequence of sluggish credit growth. Furthermore, the economy slipped into recession in 2001. In an effort to stem excess liquidity and spur lending to more-productive sectors, the Central Bank of Barbados continuously relaxed its policy stance. Between 2000 and 2001, the Bank cut its minimum deposit rate four times. Nevertheless, commercial banks' lending rates stagnated. Consequently, the central bank once again sought to regulate lending rates, instructing commercial banks to set a ceiling on the weighted average interest rates charged on loans to productive sectors. The indicative weighted average lending rate was progressively lowered from a maximum of $10 \%$ in August 2001 to $8.5 \%$ by December, yet lending rates remained relatively high even as the central bank continued to cut its minimum deposit rate, which reached an all-time low of $2.25 \%$ in the first quarter of 2004. Consequently, the central bank reintroduced loan rate ceilings in December 2002, setting the maximum average lending rate on selected loans at $8.0 \%$, which quickly translated into a fall in lending rates. However, in 2003 the regulation of loan rates was abolished.

Four years of relatively calm monetary policy spurred strong demand for credit throughout 2005 and 2006, leading to a significant tightening of liquidity in the banking system. In response, the central bank aggressively raised the minimum deposit rate from $2.25 \%$ at the beginning of 2005 to $5.25 \%$ by the end of 2006, prompting a general upward trend in lending rates. From the fourth quarter of 2006, liquidity began to build up in the banking system, largely reflecting significant foreign capital inflows and a slowdown in credit demand. In an effort to reduce the liquidity buildup, the central bank eased monetary policy, lowering the minimum deposit rate to $4.75 \%$ by the end of 2007 .

\section{III}

\section{Literature review}

The literature on interest rate pass-through is vast. Without dismissing the role of commercial bank deposit rates, ${ }^{2}$ this literature review will focus on lending rates.

\footnotetext{
2 In the euro area, De Bondt, Mojon and Valla (2005) showed that deposit rates were by and large a non-predictor of lending rates.
}

Commercial banks responded slowly on the whole to the actions of the central bank, as changes in lending rates were only a fraction of the cumulative changes in the minimum deposit rate.

\section{The Bahamas}

As in Barbados, Bahamian monetary policy revolves around the maintenance of a fixed parity between the Bahamian and United States dollars that has existed since 1973. This fixed parity is maintained in practice by keeping external reserves at $50 \%$ of the value of total notes and coins and demand liabilities of the central bank (Central Bank of the Bahamas, 1999). Since its establishment, the central bank has used interest rate controls (which include ceilings on deposit rates, a discount rate and stipulations on prime rates) in association with moral suasion to influence domestic interest rates. However, high levels of liquidity meant that the deposit interest rate ceiling could be removed in April 1994.

In the latter part of the 1990s, direct credit controls and moral suasion emerged as the core instruments of monetary policy, with interest rate policy playing a secondary role. In fact, there were only two changes in the discount rate throughout the sample period, associated essentially with shifting bank liquidity and domestic credit conditions.

The most notable characteristic of interest rate policy in the Bahamas is the synchronization between the discount rate and the prime rate. Indeed, during the review period (1995-2007), the difference between the prime rate and the central bank rate was 25 basis points each quarter. In principle, the commercial banks' prime rate is tied to the central bank discount rate, thus creating scope for it to affect domestic interest rates and economic activity.
Methodologically, most studies are of a time series nature and use an error correction model as a transformation of an autoregressive distributed lag model to study the effectiveness of interest rate transmission mechanisms. More specifically, the typical study starts implicitly with the Cottarelli and Kourelis model (1994) or its variants: 


$$
\begin{gathered}
L R_{t}=c+\alpha_{1} L R_{t-1}+\beta_{0} D R_{t}+\beta_{1} D R_{t-1} \\
+\beta_{2} D R_{t-2}+\cdots+\beta_{n} D R_{t-n}+u_{t}
\end{gathered}
$$

where $L R_{t}$ is the lending rate, $D R_{t}$ is the central bank interest rate, $u_{t}$ is the error term and $n$ stands for the optimal lag.

Equation (1) is an autoregressive distributed lag (ADL) model of order $1(n$ : ADL $(1, n))$. The impact or short-run multiplier is $\beta_{0}$ and the long-run multiplier is $\beta=\sum_{i=0}^{n} \beta_{i} /\left(1-\alpha_{1}\right)$.

A generalized error correction model corresponding to equation (1) is given by:

$$
\begin{aligned}
\Delta L R_{t}= & c+\sum_{i=1}^{n} \alpha_{i} \Delta L R_{t-i}+\sum_{i=0}^{n} \beta_{i} \Delta D R_{t-i} \\
& +\gamma\left(L R_{t-1}-\delta D R_{t-1}\right)+u_{t}
\end{aligned}
$$

where $\beta_{0}$ is the short-run multiplier,

$\delta=\beta=\sum_{i=0}^{n} \beta_{i} /\left(1-\sum_{i=0}^{n} \alpha_{i}\right)$ is the long-run multiplier,

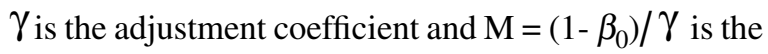
mean adjustment lag whereby the official rate is passed on to lending rates. The completeness of the pass-through is tested with either $\beta_{0}=1$ or $\delta=1$.

Tables 1-3 contain the empirical results of the short-run and long-run pass-through for the euro area, the United States and Canada, and other areas, respectively. Most authors have used time series with monthly data. Note that the magnitudes of multipliers are not necessarily comparable, since different time periods and data sources are used.
An examination of these tables reveals that the short-term impact of interest rate pass-through is smaller than the long-term impact in the majority of cases. Put differently, while short-term pass-through is often incomplete, long-term pass-through tends to be more complete. The implication is that monetary policy seems to be potent only in the long run. Short-run impacts are larger than long-run impacts in only 3 out of 44 cases, making unsustainability of interest rate pass-through an issue. Full interest rate pass-through is achieved in the short and long runs in an insignificant number of cases; full interest rate pass-through that is sustainable in this way is of course the ideal.

The only study to use a panel data methodology for the euro area is Sorensen and Werner (2006). As expected, the study uncovers a high degree of fragmentation in the retail banking sector in the euro area. In addition, it finds a great variation in interest rate pass-through at the country level and reveals a degree of stickiness in lending rate reactions to changes in market rates.

Some studies have acknowledged the issue of asymmetric interest rate pass-through; that is, the possibility of lending rates responding differently following an increase or decrease in market interest rates. The results are inconclusive, however, in that some authors have found asymmetry in interest rate pass-through and others have not (see, among others, Mojon, 2000; Borio and Fritz, 1995; Acheampong, 2004).

Where the Bahamas and Barbados are concerned, no work has dealt explicitly with the topic to the best of our knowledge. However, two papers dealing with a related topic are worth mentioning. Moore and Craigwell (2002) showed market power to be the leading determinant of interest rate pass-through in Barbados and the Caribbean. Samuel and Valderama (2006) also found that monetary policy was a key determinant in this area for Barbados. 
TABLE 1

Euro area: interest rate pass-through by study conducted

\begin{tabular}{|c|c|c|c|c|c|}
\hline Short-term loans to firms & Impact & Belgium & France & Germany & Euro area \\
\hline Cottarelli and Kourelis (1994) & $\begin{array}{l}\text { Short-term } \\
\text { Long-term }\end{array}$ & $\begin{array}{l}0.67 \\
0.87\end{array}$ & & $\begin{array}{l}0.61 \\
0.83\end{array}$ & $\begin{array}{l}0.75 \\
0.90\end{array}$ \\
\hline Mojon (2000) & $\begin{array}{l}\text { Short-term } \\
\text { Long-term }\end{array}$ & $\begin{array}{l}1.00 \\
1.00\end{array}$ & $\begin{array}{l}0.71 \\
1.00\end{array}$ & & $\begin{array}{l}0.61 \\
1.00\end{array}$ \\
\hline Donnay and Degryse (2001) & $\begin{array}{l}\text { Short-term } \\
\text { Long-term }\end{array}$ & $\begin{array}{l}0.85 \\
0.92\end{array}$ & $\begin{array}{l}0.66 \\
0.72\end{array}$ & $\begin{array}{l}0.36 \\
0.42\end{array}$ & $\begin{array}{l}0.58 \\
0.74\end{array}$ \\
\hline Toolsema, Sturm and De Haan (2001) & $\begin{array}{l}\text { Short-term } \\
\text { Long-term }\end{array}$ & $\begin{array}{l}0.76 \\
1.02\end{array}$ & $\begin{array}{l}0.53 \\
0.62\end{array}$ & & $\begin{array}{l}0.70 \\
0.80\end{array}$ \\
\hline Heinemann and Schüller (2002) & $\begin{array}{l}\text { Short-term } \\
\text { Long-term }\end{array}$ & $\begin{array}{l}0.83 \\
1.00\end{array}$ & $\begin{array}{l}0.45 \\
1.00\end{array}$ & & $\begin{array}{l}0.75 \\
1.00\end{array}$ \\
\hline Angeloni and Ehrmann (2003) & $\begin{array}{l}\text { Short-term } \\
\text { Long-term }\end{array}$ & & & & $\begin{array}{l}0.53 \\
1.00\end{array}$ \\
\hline De Bondt (2005) & $\begin{array}{l}\text { Short-term } \\
\text { Long-term }\end{array}$ & & & & $\begin{array}{l}0.19 \\
0.88\end{array}$ \\
\hline
\end{tabular}

\begin{tabular}{|c|c|c|c|c|c|}
\hline Long-term loans to firms & Impact & Belgium & France & Germany & Euro area \\
\hline Mojon (2000) & $\begin{array}{l}\text { Short-term } \\
\text { Long-term }\end{array}$ & $\begin{array}{l}0.61 \\
1.00\end{array}$ & $\begin{array}{l}0.42 \\
1.00\end{array}$ & & $\begin{array}{l}0.37 \\
1.00\end{array}$ \\
\hline Donnay and Degryse (2001) & $\begin{array}{l}\text { Short-term } \\
\text { Long-term }\end{array}$ & $\begin{array}{l}0.21 \\
0.10\end{array}$ & $\begin{array}{l}0.23 \\
0.50\end{array}$ & $\begin{array}{l}0.25 \\
0.60\end{array}$ & $\begin{array}{l}0.54 \\
0.67\end{array}$ \\
\hline Toolsema, Sturm and De Haan (2001) ${ }^{\mathrm{a}}$ & $\begin{array}{l}\text { Short-term } \\
\text { Long-term }\end{array}$ & $\begin{array}{l}0.72 \\
0.90\end{array}$ & $\begin{array}{l}0.08 \\
0.89\end{array}$ & $\begin{array}{l}0.31 \\
0.71\end{array}$ & \\
\hline Angeloni and Ehrmann (2003) & $\begin{array}{l}\text { Short-term } \\
\text { Long-term }\end{array}$ & & & & $\begin{array}{l}0.74 \\
1.30\end{array}$ \\
\hline Kwapil and Scharler (2006) & $\begin{array}{l}\text { Short-term } \\
\text { Long-term }\end{array}$ & & & & $\begin{array}{l}0.79 \\
0.57\end{array}$ \\
\hline Kaufmann and Scharler (2006) & $\begin{array}{l}\text { Short-term } \\
\text { Long-term }\end{array}$ & & & & $\begin{array}{l}0.92 \\
1.00\end{array}$ \\
\hline De Bondt (2005) & $\begin{array}{l}\text { Short-term } \\
\text { Long-term }\end{array}$ & & & & $\begin{array}{l}0.55 \\
0.80\end{array}$ \\
\hline
\end{tabular}

Source: prepared by the authors on the basis of the papers cited.

a 2002 version.

United States and Canada: interest rate pass-through by study conducted

\begin{tabular}{|c|c|c|c|c|}
\hline & \multicolumn{2}{|c|}{ United States } & \multicolumn{2}{|c|}{ Canada } \\
\hline & $\begin{array}{l}\text { Short-term } \\
\text { Impact }\end{array}$ & $\begin{array}{l}\text { Long-term } \\
\text { Impact }\end{array}$ & $\begin{array}{l}\text { Short-term } \\
\text { Impact }\end{array}$ & $\begin{array}{l}\text { Long-term } \\
\text { Impact }\end{array}$ \\
\hline \multicolumn{5}{|l|}{ Long-term loan rates } \\
\hline Cottarelli and Kourelis (1994) ${ }^{\mathrm{a}}$ & 0.41 & 0.97 & 0.78 & 0.93 \\
\hline Moazzami $(1999)^{\mathrm{b}}$ & 0.34 & 1.05 & 0.66 & 0.95 \\
\hline \multicolumn{5}{|l|}{ Short-term loan rates } \\
\hline Moazzami (1999) $)^{\mathrm{c}}$ & 0.42 & 1.07 & 0.52 & 0.80 \\
\hline Kwapil and Scharler (2006) & 0.79 & 0.57 & & \\
\hline Kaufmann and Scharler (2006) & 0.92 & 1.00 & & \\
\hline
\end{tabular}

Source: prepared by the authors on the basis of the papers cited.

a There is no clear-cut information on the duration of loans.

b Three-month Treasury bill rate.

c Overnight rate. 


\begin{tabular}{|c|c|c|c|}
\hline & Country & Short-term impact & Long-term impact \\
\hline Acheampong (2004) & Ghana & 0.26 & 0.55 \\
\hline Cottarelli and Kourelis (1994) & Jamaica & 0.15 & 0.92 \\
\hline Cottarelli and Kourelis (1994) & South Africa & 0.61 & 1.00 \\
\hline Cottarelli and Kourelis (1994) & Venezuela (Bolivarian Republic of) & 0.38 & 1.48 \\
\hline
\end{tabular}

Source: prepared by the authors on the basis of the papers cited.

\section{IV}

\section{The interest rate pass-through model}

\section{Some theoretical background}

Assume that the commercial banks anticipate some change in the central bank's minimum rate. This expectation is most likely to result from conditions in the economy, such as the inflation rate or output gaps, that affect the central bank's minimum rate policy. The expectation would very probably trigger a change in commercial banks' lending rates or deposit rates, or both. For the reasons explained in the introduction, the focus here will be on lending rates.

Let $L R_{t}^{*}$ be the desired level of the lending rate and $D R_{t}$ the central bank's minimum rate. The long-run relationship between the lending rate and minimum deposit rate can then be expressed as follows:

$$
L R_{t}^{*}=\alpha+\beta D R_{t}+e_{t}
$$

where $t$ stands for time and $\beta$ is the long-run impact of changes in the central bank's minimum rate. The longrun effects depend on demand elasticity for loans and deposits, the degree of market power, switching costs (cost of acquiring information, search and administration costs) and asymmetric information costs (adverse selection and moral hazard) (see, among others, De Bondt, 2005, pp. 43-45). To make equation (3) operative, the adjustment mechanism needs to be spelled out.

\section{A partial adjustment model}

In equation (3), $L R_{t}^{*}-L R_{t}$ represents the desired change of lending rate. One plausible model for this type of adjustment is the partial adjustment model, which can be expressed as:

$$
L R_{t}-L R_{t-1}=\lambda\left(L R_{t}^{*}-L R_{t-1}\right)
$$

where $0 \leq \lambda \leq 1$ is the coefficient of adjustment, $L R_{t}-L R_{t-1}$ represents the actual change in the lending rate and $L R_{t}^{*}-L R_{t-1}$ is the desired lending rate change.

Equation (4) expresses the actual change in the lending rate between $t-1$ and $t$ as a fraction of the desired change over the same period. Note that if $\lambda=1$ then the adjustment is instantaneous, while if $\lambda=0$ there is no adjustment and no change in the lending rate as $L R_{t}-L R_{t-1}$. A high cost of adjustment implies a low adjustment coefficient and, conversely, a low cost of adjustment yields a high adjustment coefficient.

Solving for $L R_{t}^{*}$ in equation (4) yields:

$$
L R_{t}^{*}=\frac{1}{\lambda} L R_{t}-\frac{(1-\lambda)}{\lambda} L R_{t-1}
$$

Substituting equation (5) into equation (3) yields:

$$
L R_{t}=\alpha \lambda+\beta \lambda D R_{t}+(1-\lambda) L R_{t-1}+\lambda e_{t}
$$

where $\beta_{0}=\beta \lambda$ is the short-run multiplier and $\beta=\frac{\beta_{0}}{\lambda}$ is the long-run multiplier. As can be seen, both the short-run and long-run impacts depend on adjustment cost through the adjustment coefficient. Equation (6) is an autoregressive distributed lag model of order $(1,0)$, or simply an autoregressive process. Equation (6) is also a parsimonious representation of an infinite distributed lag model: 


$$
L R_{t}=c+\sum_{i=0}^{\infty} \beta_{i} D R_{t-i}+e_{t}
$$

\section{An error correction model}

Equation (6) can alternatively be written, by subtracting $L R_{t-1}$ on both sides, as

$$
\Delta L R_{t}=\alpha \lambda+\beta \lambda D R_{t}-\lambda L R_{t-1}+\lambda e_{t}
$$

where $\Delta$ stands for the first difference operator.

Equation (8) can be rewritten, by adding and subtracting $\beta \lambda D R_{t-1}$, as

$$
\Delta L R_{t}=\alpha \lambda+\beta \lambda \Delta D R_{t}-\lambda\left(L R_{t-1}-\beta D R_{t-1}\right)+\lambda e_{t}
$$

where $\beta_{0}=\beta \lambda$ is the short-run multiplier, $\beta$ is the long-run multiplier, $\lambda$ is the coefficient of adjustment, $(1-\lambda) / \lambda$ is the mean adjustment lag and $-\log (2(1-\lambda)) / \log (1-\lambda)$ is the median lag.
Equation (9) is the error correction model (ECM) corresponding to the ADL (1.0) captured by equation (6). As can be seen, the theory of cointegration is not introduced for equation (9), since the error correction model precedes the theory of cointegration. Basically, if variables are stationary in levels, then both equation (6) and equation (9) are valid representations of the phenomenon being studied.

\section{Method of estimation}

Equation (6) and equation (9) are equivalent, as just pointed out. Both are highly non-linear in parameters. Hence, some non-linear algorithms are required to estimate them. In addition, particular attention must be paid to the issue of autocorrelation and heteroskedasticity.

To reprise, the objectives of the model estimation are to derive the short-run interest rate pass-through $\left(\beta_{0}=\beta \lambda\right)$, the long-run interest rate pass-through $(\beta)$ and the mean lag $((1-\lambda) / \lambda)$. In addition, for reasons explained in Hendry (1995, pp. 216 and 257), a median lag is also derived.

\section{Empirical results}

The data of interest are the following: for Barbados, the Central Bank of Barbados minimum deposit rate (mdrate), the weighted average rate on total loans (watloan) and the weighted average rate on selected loans (wasloan); for the Bahamas, the Central Bank of the Bahamas rate (brate) and the weighted average interest rate on loans and overdrafts of commercial bank customers (waverate).

Dealing first with Barbados, the analysis shall start by examining the time series properties of these variables in the period 1995-2007 with quarterly frequency. Figure 1 provides us with the evolution of each series. The quarterly mean stands at $4.029 \%, 11.55 \%$ and $9.87 \%$ for mdrate, watloan and wasloan, respectively. The median rate is $4.00 \%, 11.30 \%$ and $10.19 \%$ for mdrate, watloan and wasloan, respectively. There is a high degree of synchronization between the series, well captured by the significant correlation between them: 0.659 between mdrate and watloan, 0.791 between mdrate and wasloan and 0.945 between watloan and wasloan. To study the stationarity or non-stationarity of variables, two formal unit root tests are used: the augmented Dickey-Fuller (ADF) test and the PhillipsPerron (PP) test. The ultimate objective of the tests is to rule out any spurious regressions. ${ }^{3}$ Since both tests are in common use, they are not explained here.

Table 4 reveals that all three variables of interest are non-stationary at a 5\% significance level. Indeed, since the ADF and PP values are greater than the corresponding critical value for each variable in level and smaller than the critical value for each variable in first difference, it can be concluded that each series is integrated of order 1 .

Since the variables are non-stationary, there is the issue of cointegration. In any case, because the ADL estimation of equation (6) using mdrate and watloan as variables yields the same results as the error correction model from equation (9), only the ECM results are presented. A non-linear least squares estimation method (see Eviews software for details on the method) using

\footnotetext{
${ }^{3}$ This pre-testing strategy is by and large abandoned in the framework recently initiated by Pesaran, Shin and Smith (2001).
} 
FIGURE 1

Barbados: evolution of interest rates, January 1995-April 2007 (quarterly data) (Percentages)

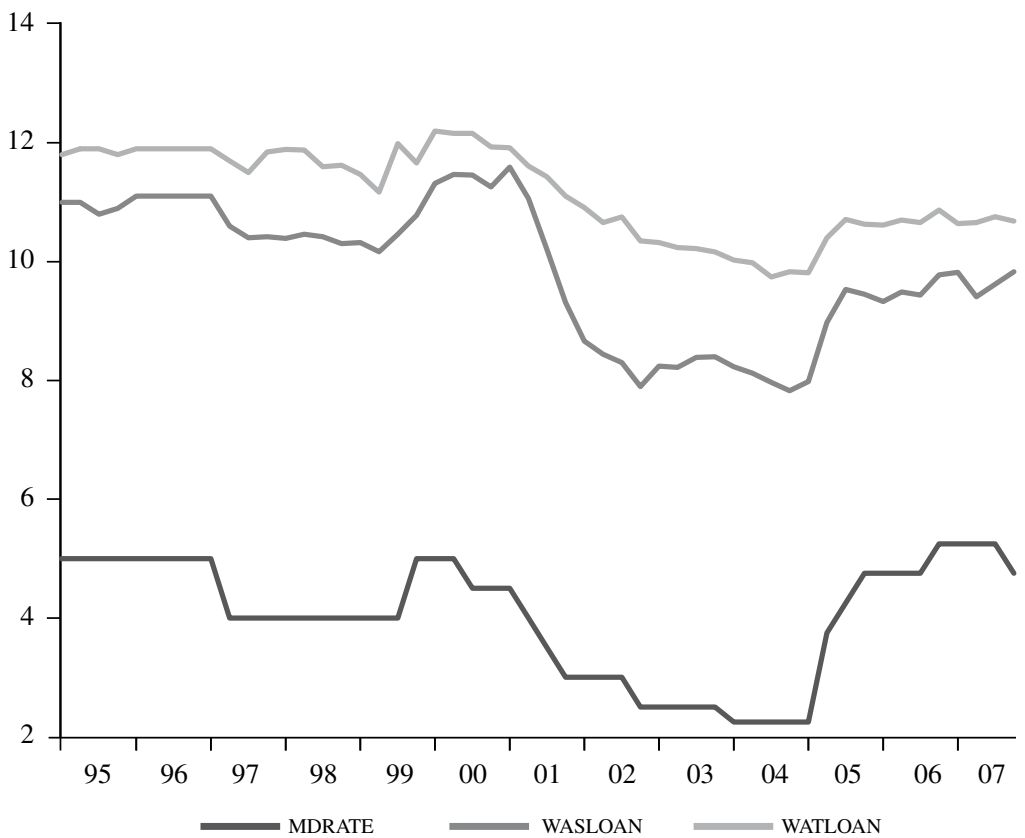

Source: Economic and Financial Statistics, Central Bank of Barbados.

mdrate: Central bank minimum rate.

wasloan: Weighted average rate on total loans.

watloan: Weighted average rate on selected loans.

TABLE 4

ADF and PP test results for Barbados, January 1995-April 2007

(Quarterly data)

\begin{tabular}{lcccc}
\hline Variable & ADF (level) & PP (level) & ADF (first difference) & PP (first difference) \\
\hline mdrate & $-1.747(\mathrm{c})$ & $-1.631(\mathrm{c})$ & $-5.382(0)^{*}$ & $-6.138(0)^{*}$ \\
wasloan & $-1.182(\mathrm{c})$ & $-1.262(\mathrm{c})$ & $-3.909(0)^{*}$ & $-8.616(0)^{*}$ \\
watloan & $-1.884(\mathrm{c})$ & $-1.563(\mathrm{c})$ & $-4.105(0)^{*}$ & $-4.584(0)^{*}$
\end{tabular}

Source: computation results based on data from Economic and Financial Statistics, Central Bank of Barbados, various issues.

Note: ADF: augmented Dickey-Fuller $t$ test; PP: Phillips-Perron $t$ test; the null hypothesis for the ADF and PP tests is that the data have a unit root; (c): with a constant only in the ADF and PP equations in level; critical values are: ADF and PP with (c): $-3.568,-2.921$ and -2.599 at the $1 \%, 5 \%$ and $10 \%$ significance levels, respectively; $(0)$ : with neither a constant nor a time trend in the first difference equations; critical values are: $-2.612,-1.948$ and -1.613 at the $1 \%, 5 \%$ and $10 \%$ significance levels, respectively; *:significant at the $5 \%$ level.

Newey-West robust standard errors has been utilized in the exercise to deal with the problems of autocorrelation and heteroskedasticity. Table 5 contains the results of the error correction model (see equation 9) for watloan.

Before interpreting the main results, it is worth noting that while the equation passes the autocorrelation test, as the $p$ value associated with the Lagrange multiplier test indicates, this is not the case for heteroskedasticity and normality. However, the use of robust standard errors takes care of heteroskedasticity detected at the $10 \%$ level. Table 5 indicates that the implied short-run impact (elasticity) is $0.104 \%$. With a $p$ value of 0.0077 associated with a Wald statistic of 7.105, short-run elasticity is statistically different from 0 at the $5 \%$ significance level. In addition, short-run elasticity is also statistically different from 1 , with a $p$ value of 0.000 associated with 
Dependent variable: $\Delta$ watloan

Method: non-linear least squares

Newey-West HAC standard errors and covariance (lag truncation=3)

\begin{tabular}{ccccc}
\hline Parameter & Coefficient & Standard error & t-statistic & Probability \\
\hline$\alpha$ & 7.950626 & 0.699985 & 11.35829 & 0.0000 \\
$\lambda$ & 0.136713 & 0.055639 & 2.457132 & 0.0176 \\
$\beta$ & 0.758633 & 0.150735 & 5.032896 & 0.0000 \\
$R^{2}$ & 0.164425 & & & \\
$D W$ & 2.43497 & & & \\
Serial correlation Lagrange & 6.7604 & Jarque-Bera & & \\
multiplier test $\left(\chi_{4}^{2}\right)^{\mathrm{a}}$ & $(0.1491)$ & normality test & & \\
White heteroskedasticity test $\left(\chi_{5}^{2}\right)$ & 9.2490 & & & \\
\hline
\end{tabular}

Source: econometric results based on data from Economic and Financial Statistics, Central Bank of Barbados, various issues.

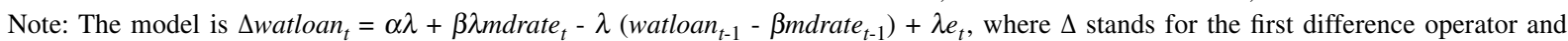
other variables are defined as above, $\lambda$ is the coefficient of adjustment, $\beta$ is the long-term impact and $\beta \lambda$ is the short-term impact. No observation was dropped.

a Figures between parenthesis correspond to $p$ values.

a Wald statistic of 530.575. Basically, there does not appear to be full interest rate pass-through in the short run. The long-run impact or elasticity is $0.759 \%$. The latter value is statistically different from 0 . However, with a $p$ value of 0.109 associated with a Wald statistic of 2.564, long-run elasticity is not statistically different from 1 . The two results combined indicate that while the pass-through impact in the short term appears to be non-existent, in the long run it is fully effective. The key question is the extent of transmission lag. To ascertain this, the mean lag and the median lag are computed. The mean lag is 6.314; that is, it takes six quarters on average for the effect of minimum interest rate changes to be transmitted to lending rates, while $50 \%$ of the effect is transmitted in just under four quarters (3.715).

To check whether the results are robust with respect to other types of loans, table 6 presents the results with selected loan rates.

Table 6 indicates that while normality is satisfied, this is not the case for autocorrelation and heteroskedasticity. The use of Newey-West heteroskedasticity- and autocorrelation-consistent (HAC) standard errors takes care of the twin problems. The results suggest that the short-run impact (elasticity) is $0.247 \%$. With a $p$ value of 0.0081 associated with a Wald statistic of 7.013 , short-run elasticity is statistically different from zero. Moreover, the short-run impact is also statistically different from 1 , as indicated by the $p$ value of 0.000 associated with a
Wald statistic of 65.293. Specifically, it is less than 1, i.e. in the short run there is no full interest rate passthrough effect. The table also indicates that long-run elasticity is $1.226 \%$. That value is statistically different from 0 . With a $p$ value of 0.324 associated with a Wald statistic of 0.973 , long-run elasticity is not statistically different from 1 at the 5\% significance level. Summing up, the two results combined indicate that interest rate pass-through is only fully effective in the long run. The mean lag, with a value of 3.965 , indicates that on average four quarters are needed for the effect of a change in the minimum deposit rate to be transmitted to the lending rates on selected loans, with $50 \%$ of the effect being transmitted in just under two quarters.

As regards the Bahamas, figure 2 shows the central bank rate (brate) and the lending rate, which is the weighted average interest rate on loans and overdrafts (waverate), as decreasing over time. The quarterly mean is $5.88 \%$ and $11.60 \%$ for brate and waverate, respectively. The median is $5.75 \%$ and $11.76 \%$ for brate and waverate, respectively. As with Barbados, there is a high degree of correlation (0.85) between the two variables.

Next, the ADF and PP tests are used to examine the stationarity or non-stationarity of each variable. Table 7 contains the results of the exercise.

According to the test values, for the Bahamas brate is non-stationary and waverate is stationary. Figure 2 raises some suspicions about the stationarity of the latter 
TABLE 6

Barbados: error correction results for average selected loans, January 1995-April 2007

(Quarterly data)

Dependent variable: $\Delta$ wasloan

Method: non-linear least squares

Newey-West HAC standard errors and covariance (lag truncation=3)

\begin{tabular}{|c|c|c|c|c|}
\hline Parameter & Coefficient & Standard error & t-statistic & Probability \\
\hline$\alpha$ & 4.837868 & 0.981456 & 4.929277 & 0.0000 \\
\hline$\lambda$ & 0.201407 & 0.075725 & 2.659700 & 0.0105 \\
\hline$\beta$ & 1.225545 & 0.228672 & 5.359395 & 0.0000 \\
\hline$R^{2}$ & 0.3184 & & & \\
\hline$D W$ & 1.0308 & & & \\
\hline $\begin{array}{l}\text { Serial correlation Lagrange } \\
\text { multiplier test }\left(\chi_{4}^{2}\right)^{\mathrm{a}}\end{array}$ & $\begin{array}{l}13.2112 \\
(0.0103)\end{array}$ & $\begin{array}{c}\text { Jarque-Bera } \\
\text { normality test }\end{array}$ & $\begin{array}{c}0.6506 \\
(0.7223)\end{array}$ & \\
\hline White heteroskedasticity test $\left(\chi_{5}^{2}\right)$ & $\begin{array}{c}9.7826 \\
(0.0816)\end{array}$ & & & \\
\hline
\end{tabular}

Source: econometric results based on data from Economic and Financial Statistics, Central Bank of Barbados, various issues.

Note: The model is $\Delta$ wasloan $_{t}=\alpha \lambda+\beta \lambda$ mdrate $_{t}-\lambda\left(\right.$ wasloan $_{t-1}-\beta$ mdrate $\left._{t-1}\right)+\lambda e_{t}$, where $\Delta$ stands for the first difference operator and other variables are defined as above, $\lambda$ is the coefficient of adjustment, $\beta$ is the long-term impact and $\beta \lambda$ is the short-term impact. No observation was dropped.

a Figures between parenthesis correspond to $p$ values.

FIGURE 2

Bahamas: evolution of interest rates, January 1995-April 2007 (quarterly data) (Percentages)

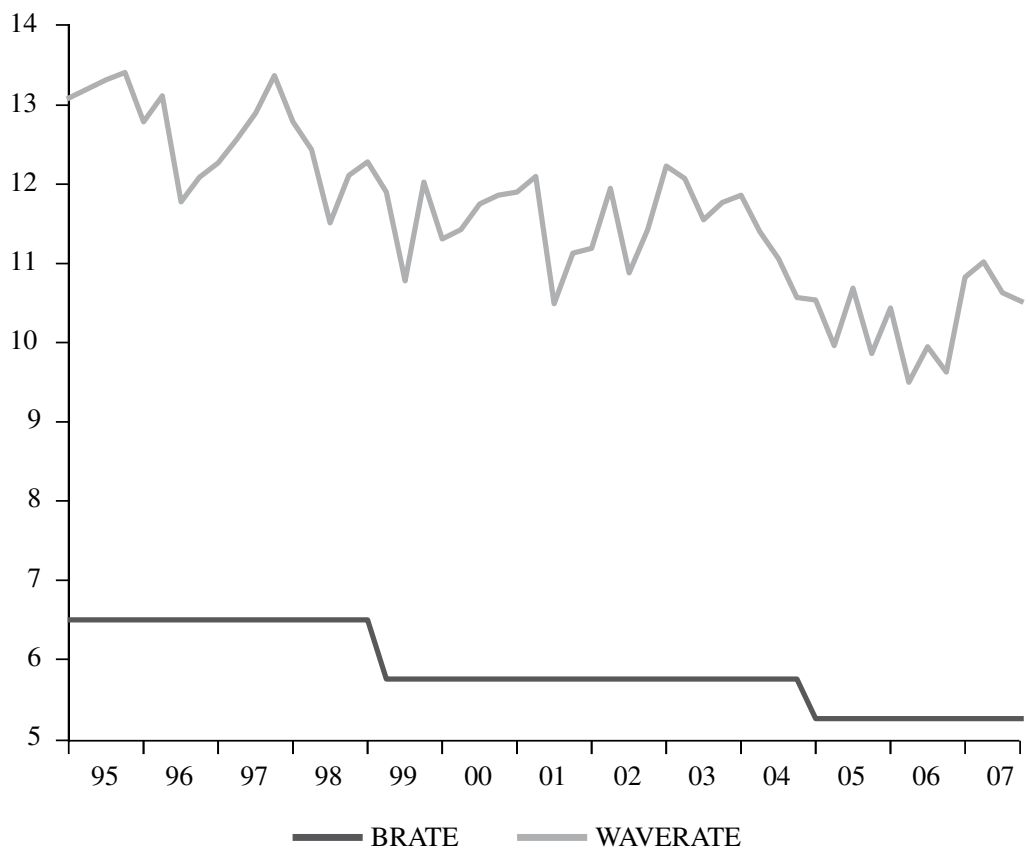

Source: prepared by the authors on the basis of data from the Central Bank of the Bahamas.

Brate: Central bank rate.

Waverate: Weighted average interest rate on loans and overdrafts. 
TABLE 7

Bahamas: ADF and PP test results, January 1995=April 2007 (Quarterly data)

\begin{tabular}{lllcr}
\hline Variable & ADF (level) & PP (level) & $\begin{array}{c}\text { ADF } \\
\text { (first difference) }\end{array}$ & $\begin{array}{c}P P \\
\text { (first difference) }\end{array}$ \\
\hline Brate & $-2.576(\mathrm{t})$ & $-2.675(t)$ & $-7.211(\mathrm{c})^{*}$ & $-7.352(c)^{*}$ \\
waverate & $-4.610(\mathrm{t})^{*}$ & $-4.658(t)$ & $-10.656(\mathrm{c})^{*}$ & $-18.972(c)^{*}$ \\
\hline
\end{tabular}

Source: computation results based on data from the Central Bank of the Bahamas.

Note: The null hypothesis for the ADF and PP tests is that the data have a unit root; $(\mathrm{t})$ : with a constant and a time trend; critical values for both tests are: $-4.148,-3.500$ and -3.174 at the $1 \%, 5 \%$ and $10 \%$ significance levels, respectively; (c): with a constant; critical values are: $-3.568,-2.921$ and -2.599 at the $1 \%, 5 \%$ and $10 \%$ significance levels, respectively. *:significant at the $5 \%$ level.

variable, however. Indeed, both the Kwiatkowski-PhillipsSchmidt-Shin (KPSS) test and the Elliot-Rothenberg-Stock (ERS) test, not presented here, indicate that waverate is non-stationary. That result is accepted.

It is legitimate to examine the relationship between the two variables using the error correction model (see equation 9). Table 8 contains the results of this exercise.

As can be seen, the equation passes the tests of autocorrelation, heteroskedasticity and normality. The short-run impact or elasticity derived from table 8 is $1.193 \%$. With a $p$ value of 0.0000 associated with a Wald statistic of 18.881 , the short-run elasticity is statistically different from 0 . Short-run elasticity is not statistically different from 1 , however, as indicated by a $p$ value of 0.481 associated with a Wald statistic of 0.496 , at least at the 5\% significance level. That is, in the short run there is a full interest rate pass-through effect. Table 8 also indicates that long-run elasticity is $1.780 \%$. The latter value is statistically different from 0 . With a $p$ value of 0.0009 associated with a Wald statistic of 11.025 , longrun elasticity is statistically greater than 1 at the 5\% significance level. Summing up, the two results combined indicate that interest rate pass-through is fully effective in the short and long run. The mean lag, with a value of 0.507 , implies that only about half a quarter is needed on average for the effect of a change in the central bank rate to be transmitted to the lending rate. This may be reflective of the high degree of synchronization between the policy rate and the lending rate.

Overall, there are three major findings. First, interest rate pass-through is fully complete in the long term in both countries. Second, while in Barbados it takes four to six quarters on average for the actions of the central bank to be transmitted to commercial banks, in the Bahamas transmission is almost instantaneous (half a quarter). Third, if the Central Bank of Barbados wishes transmission to be instantaneous, i.e. if it wants to see the lending rate increase (decrease) by 100 basis points during the quarter in which the change occurs in the minimum deposit rate, then the latter must be increased (decreased) by between 500 and 730 basis points or so. In addition, the reasons for high adjustment costs need to be investigated thoroughly. Although such an investigation is beyond the scope of this paper, such features as market power, switching costs, the demand elasticity of loans and asymmetric information costs can be cited as potential determinants (Moore and Craigwell, 2002).

Two issues that could have some impact on the results presented above merit some discussion. These are omitted variables and asymmetry in the responses of commercial banks to positive and negative monetary shocks. Since lending rates are theoretically influenced by many factors other than the minimum deposit rate (e.g. market power, switching costs, the demand elasticity of loans and asymmetric information costs), the question of interest is whether the model suffers from serious omitted variable misspecification. ${ }^{4}$ Three considerations among others can be raised. First, the estimated model (6 or 9) is a parsimonious model of a more general infinite distributed lag model (7) which implicitly captures omitted variables through the lagged minimum deposit rate variables, since the latter respond to the states of the economy over the quarters. Second, the impact of most of the so-called missing variables is captured by the adjustment coefficient, which is linked to the adjustment cost. That is, the adjustment coefficient is a kind of summary statistic of all sorts of missing variables. It may therefore be inferred that the model very probably does not suffer from a serious omitted variable misspecification. Third, a formal Ramsey regression equation specification error

\footnotetext{
4 A model, being an approximation of a certain reality, will always have some degree of misspecification. The question then is how serious the misspecification is.
} 
Dependent variable: $\Delta$ waverate

Method: non-linear least squares

Newey-West HAC standard errors and covariance (lag truncation=3)

\begin{tabular}{ccccc}
\hline Parameter & Coefficient & Standard error & t-statistic & Probability \\
\hline$\alpha$ & 0.993616 & 1.398494 & 0.710490 & 0.4808 \\
$\lambda$ & 0.663163 & 0.114208 & 5.806640 & 0.0000 \\
$\beta$ & 1.799594 & 0.240816 & 7.472908 & 0.0000 \\
$R^{2}$ & 0.3333 & & & \\
$D W$ & 2.1254 & & & \\
Serial correlation Lagrange & 6.0062 & Jarque-Bera & $(0.2590)$ & \\
multiplier test $\left(\chi_{4}^{2}\right)^{\mathrm{a}}$ & $(0.1987)$ & normality test & & \\
White heteroskedasticity test $\left(\chi_{5}^{2}\right)$ & 1.655 & & & \\
\hline
\end{tabular}

Source: econometric results based on data fromthe Central Bank of the Bahamas.

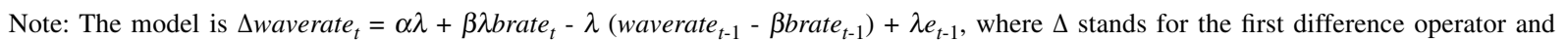
other variables are defined as above, $\lambda$ is the coefficient of adjustment, $\beta$ is the long-term impact and $\beta \lambda$ is the short-term impact. No observation was dropped.

a Figures between parenthesis correspond to $p$ values.

(RESET) test for linear regression (LR) seems to confirm that there are no omitted variables. This holds true for Barbados with a Ramsey RESET LR test value of 3.180 associated with a $p$ value of 0.365 , at least for watloan, and for the Bahamas with a test value of 4.369 associated with a $p$ value of 0.224 .
The asymmetry in responses to positive and negative monetary shocks is an important issue. While theoretically an asymmetric model is a valid construct, empirically it does not necessarily hold true, as pointed out in the literature review. This line of research is beyond the realm of the present paper.

\section{VI}

\section{Concluding remarks}

Using an error correction model derived from a partial adjustment model, this paper empirically investigates the effectiveness of central bank interest rate policy as an influence on commercial bank behaviour in Barbados and the Bahamas for the period January 1995-April 2007. A less-than-complete reaction on the part of commercial banks to changes in the central bank policy rate is an impediment to the smooth functioning of the financial system. The study finds that, for Barbados, the reaction of commercial bank lending rates to changes in the central bank minimum rate is sticky in the short run but fully complete or effective in the long run. On average, it takes about four to six quarters for the full effect of changes in the central bank policy rate to be transmitted to the economy via adjustments.
Given the size of the mean adjustment lag for Barbados, the question of interest is how to make the lending rate fully effective in the short term. According to the results of the study, in order to increase (decrease) lending rates by 100 basis points, the minimum deposit rate must be increased (decreased) by between 500 and 730 basis points or so. In addition, the reasons for the high cost of adjustment must be carefully examined. Market power, the demand elasticity of loans, switching costs and asymmetric information costs, among others, could be the elements to look at when it comes to boosting the effectiveness of interest rate policy.

The methods and frequency with which the central bank communicates its policy intentions to the public may also be a possible determinant of the effectiveness 
of monetary policy. It has been shown elsewhere (Blinder and others, 2008) that the efforts made by central banks to communicate do indeed matter when it comes to smoothing the transmission of monetary shocks. To the extent that more communication helps shape public expectations, frequent communication by a central bank on the future directions it expects its monetary policy action to take should ensure these actions are better signalled.

In the case of the Bahamas, the study finds that the reaction of commercial banks' lending rates to changes in the central bank policy rate is fully complete or effective in both the short and long run. The presence of a lower adjustment cost due to a high speed of adjustment combined with the use of moral suasion may well go a long way towards explaining why interest rate responses are fully complete in the short and long run in the Bahamas.

Overall, this comparative study demonstrates that the type of monetary policy applied, in combination with other factors, may well explain why similar economies might respond differently to monetary policy shocks. Indeed, while interest rate controls coupled with moral suasion have resulted in full pass-through of interest rates in the short term in the Bahamas, this is not the case for Barbados with its minimum deposit rate.

(Original: English)

\section{Bibliography}

Acheampong, Kwasi (2004), "Bank interest rate channel of monetary policy transmission in Ghana", Bank of Ghana Working Paper, No. 10, August.

Angeloni, Ignazio and Michael Ehrmann (2003), "Monetary transmission in the euro area: early evidence", Economic Policy, vol. 18, No. 37, London, Centre for Economic Policy Research (CEPR), October.

Barbados Business Authority (2008), Bridgetown, 5 May.

Blinder, Alan and others (2008), "Central Bank communication and monetary policy: a survey of theory and evidence", Working Paper Series, No. 898, Frankfurt, European Central Bank, May.

Borio, Claudio and Wilhelm Fritz (1995), "The response of short-term bank lending rates to policy rates: a cross-country perspective", BIS Working Papers, No. 27, Basel, Bank for International Settlements, May.

Central Bank of the Bahamas (1999), The Central Bank of the Bahamas: Celebrating 25 Years of Service, 1974-1999, Nassau.

Cottareli, Carlo and Angeliki Kourelis (1994), "Financial structure, bank lending rates and the transmission mechanism of monetary policy", IMF Staff Papers, vol. 41, No. 4, Washington, D.C., International Monetary Fund.

De Bondt, Gabe (2005), "Interest rate pass-through: empirical results for the euro area", German Economic Review, vol. 6, No.1, Oxford, Blackwell Publishing, February.

De Bondt, Gabe, Benoît Mojon and Natacha Valla (2005), "Term structure and the sluggishness of retail bank interest rates in euro area countries", European Working Paper Series, No. 518, Frankfurt, European Central Bank, September.

Donnay, Marie and Hans Degryse (2001), "Bank lending rate passthrough and differences in the transmission of a single EMU monetary policy", Center for Economic Studies Discussion Papers, No. 0117, Leuven, Katholieke Universiteit, August.

Heinemann, Friedrich and Martin Schüller (2002), "Integration benefits on EU retail markets: evidence from interest rate pass-through", ZEW Discussion Paper, No. 02-26, Mannheim, Zentrum für Europäische Wirtschaftsforschung, April.
Hendry, David (1995), Dynamic Econometrics, Oxford, Oxford University Press.

Kaufmann, Sylvia and Johann Scharler (2006), "Financial systems and the cost of channel transmission of monetary policy shocks", Working Papers, No. 116, Vienna, Oesterreichische Nationalbank, March.

Kwapil, Claudia and Johann Scharler (2006), "Limited pass-through from policy to retail interest rates: empirical evidence and macroeconomic implications", Monetary Policy and the Economy, Q4, Vienna, Oesterreichische Nationalbank.

Moazzami, Bakhtiar (1999), "Lending rate stickiness and monetary transmission mechanism: the case of Canada and the United States", Applied Financial Economics, vol. 9, No. 6, London, Taylor and Francis, December.

Mojon, Benoit (2000), "Financial structure and the interest rate channel of ЕCB monetary policy", Working Paper Series, No. 40, Frankfurt, European Central Bank, November.

Moore, Winston and Roland Craigwell (2002), "Market power and interest rate spreads in the Caribbean", International Review of Applied Economics, vol. 16, No. 4, London, Taylor and Francis.

Oliner, Stephen and Glen Rudebusch (1995), "Is there a bank lending channel for monetary policy?", Economic Review, San Francisco, Federal Reserve Bank of San Francisco.

Pesaran, M., Y. Shin and R. Smith (2001), "Bounds testing approaches to the analysis of the level relationships", Journal of Applied Econometrics, vol. 16, No. 3, John Wiley \& Sons.

Samuel, Wendell and Laura Valderrama (2006), "The monetary policy regime and banking spreads in Barbados", IMF Working Papers, No. 06/211, Washington, D.C., International Monetary Fund.

Sorensen, Kristopher and Thomas Werner (2006), "Bank interest rate pass-through in the euro area: a cross country comparison", Working Paper Series, No. 580, Frankfurt, European Central Bank, January.

Toolsema, Linden, Jan-Egbert Sturm and Jakob de Haan (2001), "Convergence of monetary transmission in EMU - new evidence", CESifo Working Paper Series, No. 465, Munich, CEsifo Group Munich, April. 